\title{
THE STATESMAN'S YEAR-BOOK 1994-95
}


Man hat behauptet, die Welt werde durch Zahlen regiert: das aber weiss ich, dass die Zahlen uns belehren, ob sie gut oder schlecht regiert werde.

GOETHE

Frederick Martin

Editors

Sir John Scott-Keltie

1864-1883

Mortimer Epstein

$1883-1926$

S. H. Steinberg

John Paxton

Brian Hunter

1911/27-1946

1946-1969

$1963 / 69-1990$

1990 


\section{THE \\ STATESMAN'S \\ YEAR-BOOK}

STATISTICAL AND HISTORICAL ANNUAL OF THE STATES OF THE WORLD

FOR THE YEAR

1994-1995

EDITED BY

BRIAN HUNTER

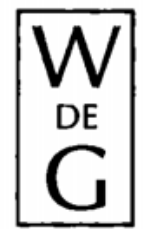

WALTER DE GRUYTER 
All rights reserved. No reproduction, copy or transmission of this publication may be made without written permission.

No paragraph of this publication may be reproduced, copied, or transmitted save with written permission or in accordance with the provisions of the Copyright, Designs and Patents Act 1988, or under the terms of any licence permitting limited copying issued by the Copyright Licensing Agency, 90 Tottenham Court Road, London W1P 9HE.

Any person who does any unauthorised act in relation to this publication may be liable to criminal prosecution and civil claims for damages.

Published annually since 1864

131 st edition first published 1994 by

THE MACMILLAN PRESS LTD

London and Basingstoke and

WALTER DE GRUYTER \& CO.

Berlin

Typeset in Great Britain by
A. J. LATHAM LIMITED
Dunstable, Bedfordshire

Printed in England by BPC Hazell Books Ltd

A member of

The British Printing Company Ltd

ISBN 3-11-014452-2 